\title{
ETV3 wt Allele
}

National Cancer Institute

\section{Source}

National Cancer Institute. ETV3 wt Allele. NCI Thesaurus. Code C52869.

Human ETV3 wild-type allele is located within 1q21-q23 and is approximately $17 \mathrm{~kb}$ in length. This allele, which encodes ETS translocation variant 3 protein, is involved in the repression of transcription by RNA polymerase II. 